\title{
Seagrasses are negatively affected by organic matter loading and Arenicola marina activity in a laboratory experiment
}

\author{
Laura L. Govers · Timon Pieck · Tjeerd J. Bouma • \\ Wouter Suykerbuyk • Alfons J. P. Smolders • \\ Marieke M. van Katwijk
}

Received: 6 May 2013 / Accepted: 5 March 2014 / Published online: 15 March 2014

(C) Springer-Verlag Berlin Heidelberg 2014

\begin{abstract}
When two ecosystem engineers share the same natural environment, the outcome of their interaction will be unclear if they have contrasting habitat-modifying effects (e.g., sediment stabilization vs. sediment destabilization). The outcome of the interaction may depend on local environmental conditions such as season or sediment type, which may affect the extent and type of habitat modification by the ecosystem engineers involved. We mechanistically studied the interaction between the sedimentstabilizing seagrass Zostera noltii and the bioturbating and sediment-destabilizing lugworm Arenicola marina, which sometimes co-occur for prolonged periods. We investigated (1) if the negative sediment destabilization effect of A. marina on $Z$. noltii might be counteracted by positive biogeochemical effects of bioirrigation (burrow flushing) by $A$. marina in sulfide-rich sediments, and (2) if previously observed nutrient release by A. marina bioirrigation could affect seagrasses. We tested the individual and combined effects of $A$. marina presence and high porewater sulfide concentrations (induced by organic matter addition)
\end{abstract}

Communicated by Ulrich Sommer.

L. L. Govers $(\bowtie) \cdot$ T. Pieck · W. Suykerbuyk ·

M. M. van Katwijk

Department of Environmental Science, Faculty of Science,

Radboud University Nijmegen, Heyendaalseweg 135,

6525 AJ Nijmegen, The Netherlands

e-mail: lauralgovers@gmail.com

T. J. Bouma $\cdot$ W. Suykerbuyk

Department of Spatial Ecology, NIOZ Yerseke Royal Netherlands

Institute for Sea Research, Yerseke, The Netherlands

\section{A. J. P. Smolders}

Department of Aquatic Ecology and Environmental Biology,

Radboud University Nijmegen, Nijmegen, The Netherlands on seagrass biomass in a full factorial lab experiment. Contrary to our expectations, we did not find an effect of A. marina on porewater sulfide concentrations. A. marina activities affected the seagrass physically as well as by pumping nutrients, mainly ammonium and phosphate, from the porewater to the surface water, which promoted epiphyte growth on seagrass leaves in our experimental set-up. We conclude that A. marina bioirrigation did not alleviate sulfide stress to seagrasses. Instead, we found synergistic negative effects of the presence of A. marina and high sediment sulfide levels on seagrass biomass.

Keywords Bioturbation - Bioirrigation · Biogeochemistry $\cdot$ Epiphytes $\cdot$ Lugworm

\section{Introduction}

Ecosystem engineers are "organisms that directly or indirectly modulate the availability of resources to other species, by causing physical state changes in biotic or abiotic materials. In doing so, they modify, maintain and create habitats" (Jones et al. 1994). The intertidal zone is a dynamic area, which is subject to many stressors such as waves and currents when submerged, but also to desiccation stress when exposed. A wide range of ecosystem engineers inhabit the dynamic intertidal flats (Passarelli et al. 2013), which may cause different and sometimes opposing habitat modifications (Bouma et al. 2009). In general terms, benthic engineering species living on the intertidal flats can be divided into epibenthic engineers, which live on top of the sediment, and endobenthic engineers, which mainly live within the sediment. Epibenthic ecosystem engineers, such as seagrasses and oyster reefs, typically modify the sedimentary habitat mainly by affecting 
hydrodynamics and sediment dynamics with their physical structures, which protrude into the water column (Bos et al. 2007; Bouma et al. 2005; Koch et al. 2009). In contrast, endobenthic engineers, such as several polychaete species, typically modify the sedimentary habitat by bioturbation (sediment reworking) and bioirrigation (burrow flushing) (Cadée 2001; Meysman et al. 2006; Reise 2002).

In recent decades, there has been a growing interest in the way in which ecosystem engineers can benefit other species (Bertness and Leonard 1997; Bruno et al. 2003), partly because such interactions can be highly relevant for coastal restoration projects (Crain and Bertness 2006; Van Katwijk et al. 2009). More recently, researchers have emphasized the importance of negative engineering interactions from an ecological and restoration perspective (Suykerbuyk et al. 2012; Van Wesenbeeck et al. 2007). This raises the questions how ecosystem engineers can interact, whether the engineering might have positive and negative effects at the same time, and how the outcomes depend on environmental conditions. In this study, we addressed this issue using sediment-stabilizing seagrasses (Zostera noltii) and bioturbating and bioirrigating lugworms (Arenicola marina) as model organisms.

Seagrasses are epibenthic ecosystem engineers that can improve their own growing conditions by stabilizing the sediment (Bos and van Katwijk 2007; Christianen et al. 2013; Fonseca 1989) and by attenuating waves and currents (Fonseca and Cahalan 1992; Peralta et al. 2008; Peterson et al. 2004), resulting in the accumulation of small sediment particles and suspended organic matter (Granata et al. 2001; Van der Heide et al. 2011). These ecosystem characteristics have also been identified for our model species $Z$. noltii (Bouma et al. 2005; Brun et al. 2009). On the other hand, the entrapment of suspended organic matter and the production of organic matter by seagrasses often results in high sulfate reduction rates in the sediment, leading to the production of sulfides (Jørgensen 1982), which are toxic to the seagrasses (Borum et al. 2005; Calleja et al. 2007; Lamers et al. 2013; Mascaró et al. 2009). However, Van der Heide et al. (2012) showed that a common symbiosis between lucinid bivalves, their sulfide-oxidizing gill symbionts and seagrass greatly reduces the sulfide stress to the seagrasses. Although this symbiosis is less prevalent in temperate systems (Van der Heide et al. 2012), it is conceivable that other benthic organisms than lucinids might play a role in alleviating sulfide stress to seagrasses in temperate areas.

The sediment-stabilizing seagrass beds are inhabited by numerous species of bioturbating animals, which rework and ventilate the sediment. The lugworm A. marina is such a bioturbator, which is widely distributed in the North Atlantic (Cadée 1976; Flach and Beukeman 1994), and creates burrows and clearly visible casts that can reach a height of over $5 \mathrm{~cm}$ (personal observations). These bioturbating animals physically destabilize the sediment by their sediment-reworking activities (Cadée 1976; Valdemarsen et al. 2011). In addition, they strongly affect local biogeochemistry (1) by modifying sediment texture; (2) by dispersing solid particles; and (3) by bioirrigation, which is the enhanced exchange of solutes between the porewater and the overlying water column (Banta et al. 1999; Meysman et al. 2006; Volkenborn et al. 2007; Volkenborn and Reise 2006; Wendelboe et al. 2013). Bioirrigation by $A$. marina has been observed to result in the release of ammonium from sand flats inhabited by A. marina to the water column in an open field-flume system (Asmus and Asmus 1998; Asmus et al. 1998) and in situ (Papaspyrou et al. 2007). Additionally, an increase in porewater nutrients has been observed in field experiments where A. marina was excluded (Volkenborn et al. 2007; Volkenborn and Reise 2006).

Interestingly, contrasting interactions have been observed between Z. noltii and A. marina. In some areas, the physical habitat modification by A. marina has been shown to hamper the growth of Z. noltii (Cadée 1976; Philippart 1994; Suykerbuyk et al. 2012). The activities of this worm can lead to seagrass plants being buried, which may completely suppress seagrass settlement in certain areas, and $Z$. noltii has been found to retreat to areas with compact sediments or natural shell layers, which are unsuitable for A. marina (Philippart 1994; Reise 2002; Rijken 1979). In other areas, however, dense seagrass meadows can sometimes reduce $A$. marina bioturbation as their thick rhizome mat restricts funnel formation (Philippart 1994; Valentine et al. 1994), and by shading the sediment, which hampers the growth of epiphytobenthos, an important food source for A. marina (Rijken 1979). In some locations, Z. meadows co-occur with A. marina (Jacobs et al. 1983; personal observations). Several authors (Philippart 1994; Suykerbuyk et al. 2012) suggested that seagrass coverage may even be positively correlated with the density of juvenile A. marina, which do not cause such unfavorable sediment-destabilizing effects as adults, and may benefit the seagrass by aerating the sediment and increasing nutrient availability.

Ecosystem engineering by A. marina might thus potentially have positive as well as negative effects on the seagrass $Z$. noltii, and it is still unclear how the effect may depend on the environmental conditions. The physical effects of bioturbation on seagrasses have been relatively well studied (Philippart 1994; Reise and Kohlus 2007; Suykerbuyk et al. 2012), but its biogeochemical effects on seagrasses still remain to be elucidated. Hence, we investigated how the combination of altered biogeochemistry and physical disturbance by A. marina bioturbation could affect the seagrass $Z$. noltii in sediments with contrasting 
organic matter contents. We hypothesized that A. marina could have positive effects on $Z$. noltii growth by alleviating sulfide toxicity in organically enriched sediments through sediment aeration and pumping to the overlying water column. However, the same flushing could lead to an increased release of nutrients to the water column, which might potentially cause toxic effects (ammonium) or epiphyte blooms (ammonium and phosphate).

\section{Materials and methods}

\section{Experimental design}

To test the individual and interacting effects of A. marina bioturbation and bioirrigation and sulfide toxicity (organic matter addition) on $Z$. noltii biomass, we designed a full factorial experiment, in which aquaria were provided with organic matter $(\mathrm{OM})$, A. marina (Ar), seagrass $(\mathrm{Sg})$, or a combination of these treatments, resulting in a total of eight different treatments: control, OM, Ar, Sg, OMAr, OMSg, $\mathrm{SgAr}$ and $\mathrm{OMSgAr}$. For the OM treatment, $2 \mathrm{~g} \mathrm{~L}^{-1}$ organic matter $\left(1 \mathrm{~g}\right.$ starch $+1 \mathrm{~g}$ cellulose $\mathrm{L}^{-1}$ sediment) was mixed into the sediment to stimulate sulfide production (Govers et al., in revision; Peralta et al. 2003), before the start of the experiment. We used five replicates per treatment, resulting in 40 experimental units, which were randomly placed in a water bath. During the experiment, the synthetic seawater was completely refreshed twice a week.

The experiment was conducted in 24-L glass aquaria (le ngth $\times$ width $\times$ height $=20 \times 20 \times 60 \mathrm{~cm}$ ), which were filled with a $30 \mathrm{~cm}$ sediment layer (12 L) and a $25-$ to $30-\mathrm{cm}$ water layer, which was prepared from deionized water and Tropic Marin synthetic sea salt; salinity levels were comparable to levels measured in the field (27-29 practical salinity units). An aquarium pump and aquarium bubbler in each aquarium aerated the surface water. Aquaria were placed in a large water bath at $20{ }^{\circ} \mathrm{C}$. Light intensity was set at $300 \mu \mathrm{mol} \mathrm{m} \mathrm{m}^{-2} \mathrm{~s}^{-1}$, with a day-night cycle of 14-10 h, which is comparable to light conditions in the field (Isaksen and Finster 1996). The experiment lasted for 28 days and all treatments were run simultaneously.

\section{Origins of sediment and biological materials}

Sediment, seagrass (Z. noltii) and lugworms (A. marina) were obtained from the mudflats of the Oosterschelde area $\left(51^{\circ} 39^{\prime} \mathrm{N}, 4^{\circ} 01^{\prime} \mathrm{E}\right)$, the Netherlands. Sandy sediment, with a median grain size of $180 \mu \mathrm{m}$ and $0.6 \%$ organic matter, was collected on a single day at the exposed Dortsman mudflats (Suykerbuyk et al. 2012), transported to the laboratory in Nijmegen (the Netherlands), sieved $(5 \mathrm{~mm})$ to remove coarse material and macrobenthos and subsequently mixed to homogenize the sediment. This meant that mud snails (Hydrobia ulvae), which were smaller than $5 \mathrm{~mm}$, were present $\left(289 \pm 25 \mathrm{~m}^{-2}\right)$ in the experiment (Fig. 4), providing a source of epiphyte grazing. We found no treatment effect on Hydrobia spp. densities $(P=0.288)$ and the observed densities were not very high compared to the field densities of $>4,000 \mathrm{~m}^{-2}$ (personal observations) and $20,000 \mathrm{~m}^{-2}$ (Grilo et al. 2012). $Z$. noltii was collected in the field at the start of the growing season, and was immediately planted in the prepared sediment in the lab, at densities of 50 shoots per aquarium $\left(1,250 \mathrm{~m}^{-2}\right)$, which represents the average density at the start of the growing season (Vermaat and Verhagen 1996). A. marina were obtained from a professional collector (' $t$ Zeepiertje, Yerseke). On the day of collection, adult $A$. marina with a length of $20-25 \mathrm{~cm}$ were put in the aquaria, at densities of two individuals per aquarium $\left(50 \mathrm{~m}^{-2}\right)$, which is similar to high adult A. marina densities in the field (Suykerbuyk et al. 2012). The A. marina were retrieved alive after the termination of the experiment.

\section{Sample collection and analysis}

During the experiment, sediment porewater samples were collected on seven occasions $(t=0,3,7,14,19,24$, 28 days), using vacuumed flasks connected to soil moisture samplers (Rhizons; Eijkelkamp Agrisearch Equipment, Giesbeek, the Netherlands). Ten milliliters of porewater was collected at each sampling occasion for sulfide analysis, and $20 \mathrm{~mL}$ was sampled at the end of the experiment for both sulfide and nutrient analysis. The rhizons were placed horizontally, in the central part of all aquaria, at a depth of $5 \mathrm{~cm}$ in the sediment, which is the average rooting depth of $Z$. noltii. Similar porewater samples were simultaneously taken at depths of 10 and $20 \mathrm{~cm}$. These porewater samples were immediately used to measure sulfide concentrations in a mixture of $50 \%$ sample and $50 \%$ sulfide anti-oxidation buffer (Lamers et al. 1998) using a calibrated ion-specific silver sulfide electrode. At the end of the experiment ( $t=28$ days), we used the same method to collect porewater samples for nutrient concentration measurements $(20 \mathrm{~mL})$, which were frozen and later analyzed in the lab. Surface water samples were collected through rhizons completely submerged in the water layer, in order to filter the water samples prior to analysis. Porewater and surface water ammonium and ortho-phosphate concentrations were measured colorimetrically (Skalar and Seal autoanalyzer), using ammonium molybdate and salicylate. Nitrate was determined by sulfanilamide, after reduction of nitrate to nitrite in a cadmium column (Wood et al. 1967). All nutrients were measured at the analytical lab of the Royal Netherlands Institute for Sea Research (NIOZ) in Yerseke, the Netherlands. 
Seagrass was harvested at the end of the experiment $(t=28$ days), after which epiphytes were carefully removed and plants were divided into leaves, sheaths, rhizomes and roots. Total dry weight (g DW) was determined after drying the material for $48 \mathrm{~h}$ at $60{ }^{\circ} \mathrm{C}$.

\section{Statistical analysis}

All results are summarized as mean \pm SE. Prior to analysis, extreme outliers were omitted based on Dixons' quantile (Q)-test (Dean and Dixon 1951), and normality of the data was tested with a Shapiro-Wilk test and QQ-plots. Nonnormally distributed data were $\log$ transformed prior to analysis. We used a three-factor repeated measure ANOVA to compare the effects of the treatments on porewater sulfide concentrations. All other data were tested using a three-way (nutrients) or two-way (biomass) ANOVA. Relevant statistical results are presented in the figure legends and in the results section. Differences with $P<0.05$ were considered significant. All statistical tests were performed with IBM SPSS Statistics 20.0 and R 2.15.

\section{Results}

We successfully induced sulfide production in the sediment by adding organic matter (OM), which enabled us to study the effects of A. marina on porewater sulfide concentrations (Fig. 1a). We obtained similar results from the sediment sulfide measurements at depths of 10 and $20 \mathrm{~cm}$, so these results are not presented separately. We observed a sulfide peak in the porewater in the OM treatments on day 7, with sulfide levels of $450-800 \mu \mathrm{mol} \mathrm{L} \mathrm{L}^{-1}$ in the OM, OMAr and OMSg treatments, and $>4,000 \mu \mathrm{mol} \mathrm{L}^{-1}$ in the $\mathrm{OMSgAr}$ treatment. Sulfide levels in the OM treatments (Fig. 1a) decreased after the observed sulfide peak to levels similar to those in the other treatments $\left(10-100 \mu \mathrm{mol} \mathrm{L}^{-1}\right.$; Fig. 1b). On day 21, a small sulfide peak was observed (25-250 $\left.\mu \mathrm{mol} \mathrm{L}^{-1}\right)$ due to degradation of the organic matter $(0.6 \%)$, which was naturally present in the sediment. Contrary to our hypothesis, A. marina had not decreased porewater sulfide concentrations at any monitoring moment during our experiment. Similarly, the presence of Z. noltii did not decrease porewater sulfide concentrations. This was also contrary to our expectations, as seagrasses are known to leak oxygen from their roots, which can decrease sulfate reduction rates in the sediment. After the strong initial increase, especially in the OM treatments, porewater sulfide concentrations showed a decrease, very probably due to diffusion or outgassing of (hydrogen) sulfides from the sediment to the water column and subsequently to the air.

Porewater ammonium concentrations were significantly lowered in the presence of A. marina $(P<0.001$; Fig. 2a),
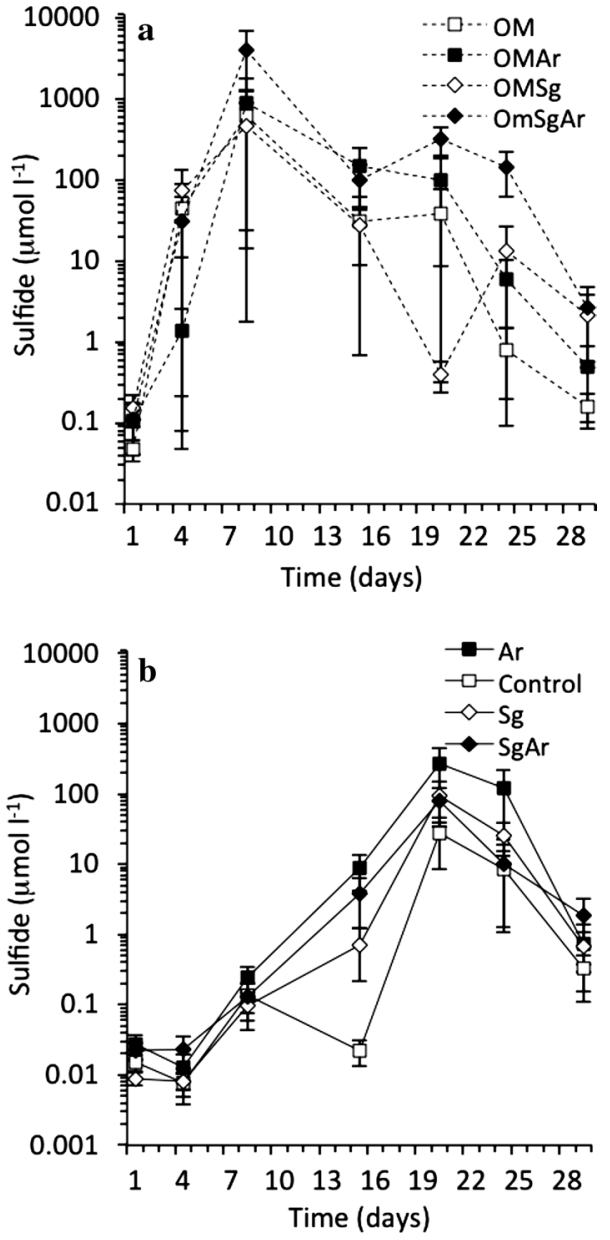

Fig. 1 Porewater sulfide concentrations of treatments a with organic matter addition and $\mathbf{b}$ without organic matter addition. Added organic matter (OM; dashed lines) interacted with both Arenicola marina (Ar) and seagrass (Zostera noltii) ( $\mathrm{Sg}$ ) to increase sulfide concentrations in the porewater $(\mathrm{OM} \times \operatorname{Ar} P=0.009, \mathrm{OM} \times \operatorname{Sg} P=0.049)$. A highly significant interaction between organic matter addition, $A$. marina and $Z$. noltii $(O M S g A r)$ led to the highest porewater sulfide concentrations $(P<0.001)$ (a). The presence of $A$. marina did not significantly affect porewater sulfide concentrations (black symbols, $P=0.075)$. Error bars represent SE $(n=5)$. Note that the $y$-axis is displayed on a logarithmic scale

whereas surface water ammonium concentrations were significantly increased in the presence of A. marina $(P<0.05$; Fig. 2b). Nevertheless, porewater ammonium concentrations were still more than ten times higher than surface water concentrations. Porewater nitrate (Fig. 2c) and phosphate (Fig. 2e) levels were not affected by any of the treatments, but surface water nitrate concentrations were significantly elevated through an interaction between organic matter and A. marina $(P<0.05$; Fig. $2 \mathrm{~d})$, and the presence of $A$. marina significantly increased the surface water phosphate $(P<0.001$; Fig. 2f).

Total seagrass biomass per square meter was more than 12 times higher in the seagrass control treatment $(\mathrm{Sg})$ than 
Fig. 2 a Porewater ammonium $\left(\mathrm{NH}_{4}\right)$ concentrations were significantly $(P<0.001)$ lowered by the presence of $A$. marina, while b surface water $\mathrm{NH}_{4}$ concentrations increased significantly $(P=0.032)$ as a result of bioturbation and bioirrigation by A. marina. The presence of seagrass $(\mathrm{Sg})$ or the addition of organic matter $(\mathrm{OM})$ affected neither porewater $\mathrm{NH}_{4}$ nor surface water $\mathrm{NH}_{4}$ concentrations. c Porewater nitrate $\left(\mathrm{NO}_{3}\right)$ concentrations were not affected by any of the treatments, whereas $\mathbf{d}$ surface water $\mathrm{NO}_{3}$ was significantly elevated in the OMAr treatment $(P=0.019)$. e Porewater phosphate $\left(\mathrm{PO}_{4}\right)$ concentrations were not affected by any of the treatments, but $\mathbf{f}$ surface water $\mathrm{PO}_{4}$ concentrations were highly elevated in the Ar treatments $(P<0.001)$. Error bars represent SE $(n=5)$. For abbreviations, see Fig. 1
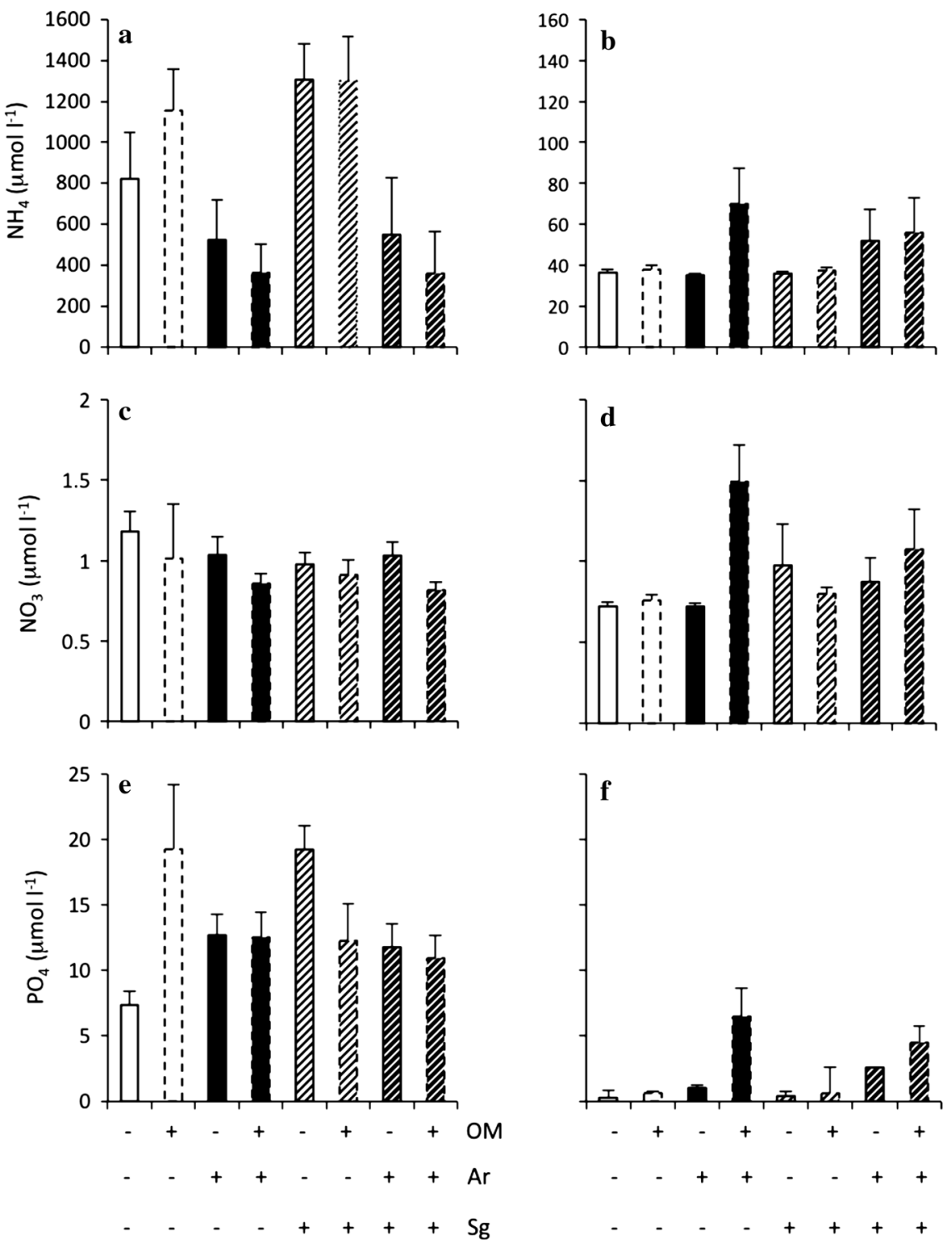

in the other treatments (Fig. 3a). Both A. marina (Ar) and organic matter $(\mathrm{OM})$ had strong negative effects on seagrass biomass $(P<0.001$ and $P<0.001$, respectively). The interaction of both stressors (OMAr) even led to a synergistic negative effect $(P<0.001)$, as almost all of the seagrass died in this treatment, resulting in an extremely low $\left(<0.1 \mathrm{~g} \mathrm{DW} \mathrm{m}^{-2}\right)$ seagrass biomass. Additionally, the seagrass leaves in the control treatments all had a healthy green color throughout the experiment, whereas the leaves in all other treatments gradually died off as a result of epiphyte overgrowth. As a consequence of the elevated surface water nutrient levels, epiphyte biomass per leaf (Fig. 3b) increased strongly in the A. marina treatments $(P<0.001)$, reaching values of up to 100 times more epiphyte biomass than leaf biomass. Organic matter addition also led to significantly more epiphytes per leaf $(P=0.036)$, but this was the result of the absolute decrease in leaf biomass rather than of the absolute increase in epiphyte biomass (as there were no significant effects of organic matter addition on absolute epiphyte biomass; results not shown). Epiphyte biomass was extremely high in the A. marina treatments, which meant that the leaves were completely overgrown in these treatments (Fig. 4).

\section{Discussion}

Our hypothesis that oxygenation of the sediment by $A$. marina bioturbation and bioirrigation would potentially alleviate sulfide toxicity for seagrass in temperate systems was falsified. In our experiment, A. marina had no net beneficial effect on seagrass growth through reducing porewater sulfide concentrations. Secondly, we showed that the sediment-stabilizing seagrass and the sediment-reworking 

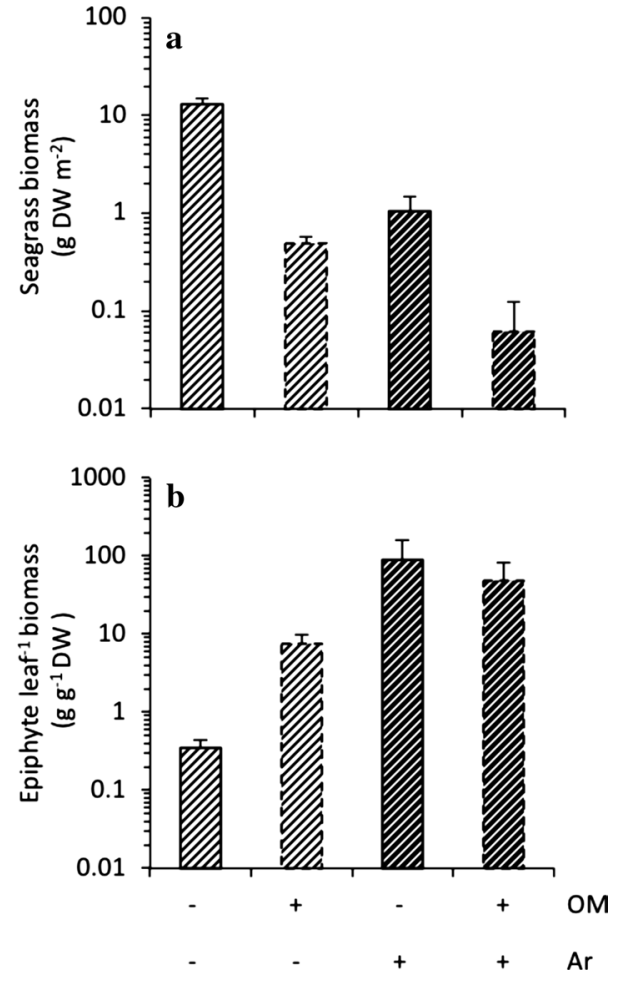

Fig. 3 a Total seagrass biomass and b epiphyte biomass per leaf in the $\mathrm{Sg}$ treatments. A. marina activity negatively affected seagrass biomass $(P<0.001)$ and the addition of organic matter $(\mathrm{OM})$ also had a significant negative effect on a Sg biomass $(P<0.001)$. There was also a significant negative interaction between $\mathrm{OM}$ and Ar $(P<0.015)$. A. marina activity significantly increased the quantities of $\mathbf{b}$ epiphytes on seagrass leaves $(P<0.001)$, and organic matter addition also significantly increased epiphyte biomass on the leaves $(P<0.001)$. Error bars represent SE $(n=5)$. Note that the $y$-axis is displayed on a logarithmic scale. For abbreviations, see Fig. 1

A. marina are not only physically contrasting ecosystem engineers [as is well known from the literature; e.g., Suykerbuyk et al. 2012], but that they also display contrasting biogeochemical behavior. Whereas seagrasses are known to be important nutrient sinks (Romero et al. 2006), A. marina increased nutrient fluxes from the sediment to the surface water in our experiment, as was also observed in the field by Asmus and Asmus (1998) on bare mudflats. In our experiment, in the presence of seagrass, these fluxes promoted the growth of epiphytes on the seagrass leaves. In addition, the synergistic negative effects of organic matter addition (sulfide stress) and the presence of A. marina (physical and biogeochemical disturbance) led to the almost complete disappearance of seagrass biomass.

\section{Sulfide biogeochemistry}

Bioturbation is known to alter sediment biogeochemistry by increasing oxygen penetration into the sediment (Banta et al. 1999; Kristensen 2000; Timmermann et al. 2006), but also by increasing or changing the input of organic matter through sediment reworking (Hansen et al. 1996; Hines and Jones 1985; Kristensen 2000; Kristensen et al. 2012). Bioturbation is therefore expected to have two contrasting effects on sulfate reduction rates in the sediment; increased organic matter input by sediment reworking stimulates sulfate reduction (Hansen et al. 1996; Hines and Jones 1985; Holmer and Nielsen 1997; Valdemarsen et al. 2010), while on the other hand, sulfate reduction rates may also be reduced by the increased oxygen input that results from bioirrigation (Banta et al. 1999; Nielsen et al. 2003). Our nutrient measurements show that active bioirrigation by $A$. marina took place, as we found decreased porewater nutrient concentrations and increased surface water nutrient concentrations in the A. marina treatments. However, contrary to our expectations, $A$. marina did not decrease porewater sulfide concentrations. This indicates that $A$. marina may reduce sulfate reduction rates only locally, in a narrow zone of 5-15 $\mathrm{mm}$ surrounding the burrow (Nielsen et al.
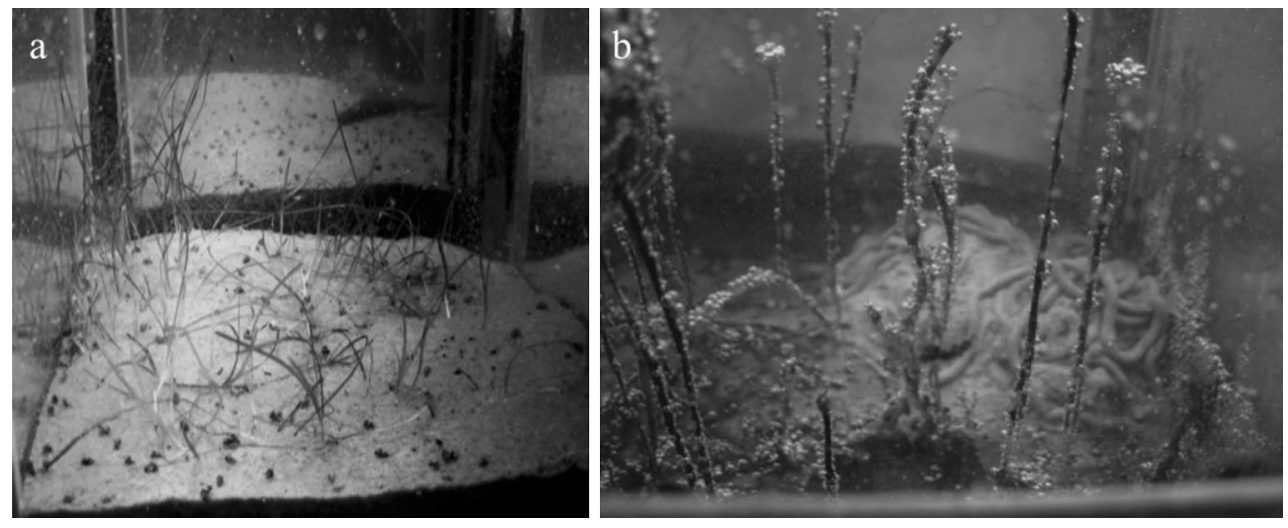

Fig. 4 Photographs of a healthy Z. noltii in the Sg treatment and b epiphyte-overgrown Z. noltii in the Ar treatment. For abbreviations, see Fig. 1 
2003). Additionally, the fact that we did not find decreasing sulfide concentrations in the A. marina treatments may be explained by A. marina respiration, which consumes a considerable proportion of the oxygen that is pumped into the burrow (Timmermann et al. 2006). Sediment sulfide concentrations became very high in the OMSgAr treatment $(>4,500 \mu \mathrm{M})$, possibly because the combined effect of increased sulfide production and epiphyte growth resulted in seagrass roots dying off, which in turn stimulated sulfide production by providing easily degradable organic matter.

Nutrients, seagrass and epiphytes

As bioturbation is known to stimulate decomposition rates (Andersen and Kristensen 1992; Banta et al. 1999), one might expect an increase in the porewater nutrient concentrations (Meysman et al. 2006). However, in our experiment we found exactly the opposite in the A. marina treatments: porewater nutrient concentrations decreased while surface water nutrient concentrations increased. These results are in agreement with results found in open systems. Volkenborn et al. (2007) found that porewater ammonium and ortho-phosphate increased in plots where A. marina was excluded and Asmus and Asmus (1998) observed a release of ammonium from A. marina sand flats.

It is well known that the sediment-reworking activities of A. marina can hamper seagrass growth by burying or uprooting the plants (Cadée 1976; Philippart 1994; Suykerbuyk et al. 2012; Valdemarsen et al. 2011). However, our experiment included the biogeochemical effects of bioturbation, and showed that these could, in conjunction with physical disturbance, also negatively affect seagrass growth. We found a major decrease in seagrass biomass in all $A$. marina treatments, and even more so in the interactive OMSgAr treatment, which was probably due to the synergistic effects of sulfide toxicity and epiphyte bloom as a result of nutrient release. Soil sulfide toxicity may have triggered dieback of the root system, which in turn could have led to even higher sulfide production rates. Excessive epiphyte growth on seagrass leaves is known to reduce light intensity and decrease the uptake of carbon for photosynthesis, which may lead to reduced growth levels and eventually to seagrass leaves dying off (Sand-Jensen 1977; Tomasko and Lapointe 1991).

Several studies have also reported that A. marina bioturbation activities stimulate the growth of bacteria in the burrow system (Ashforth et al. 2011; Grossmann and Reichardt 1991), which is called "gardening" (Hylleberg 1975). This gardening activity, which is an additional ecosystem engineering property of bioturbating organisms such as A. marina, might also extend to the epiphytobenthos, as A. marina might stimulate the growth of epibenthic algae by increasing the flow of nutrients to the surface, thus stimulating the growth of its own food source. We observed (but did not quantify) this in our A. marina treatments (Fig. 4). This potential positive feedback in systems dominated by $A$. marina deserves further investigation.

The experiment was conducted in aquaria with a refreshment rate of twice a week. Although this is much lower than the refreshment rate in natural systems, our findings suggest that increased surface water nutrient availability could severely affect seagrasses by promoting epiphyte growth in sheltered bays and estuaries with limited water movement. And even though nutrient loads and subsequent epiphyte loads may have been aggravated by our experimental set-up, we still expect similar effects, though less severe, to occur in field situations, as the nutrient efflux from the sediment passes through the canopy. In addition, in more exposed systems, with higher current velocities, A. marina can still increase the nutrient load of the system, as shown by Asmus et al. (1998) and Asmus and Asmus (1998), and nutrient release may even rise with increasing current velocities (Asmus et al. 1998), although these loads may not necessarily promote epiphyte blooms. Nonetheless, physical burial or smothering by A. marina may have more detrimental effects on seagrasses in the field than biogeochemical disturbance by bioturbation and bioirrigation. At the same time, however, increased epiphyte loading as a result of bioirrigation may render seagrasses more vulnerable to physical disturbance by sediment reworking. Hence, our study contributes to the unraveling of mechanisms that shape the complex interaction between seagrasses and bioturbating animals, which inhabit seagrass beds, rather than predicting the precise effect of bioirrigation by A. marina on seagrasses in a field situation.

\section{Implications and conclusions}

Contrary to our expectations, bioturbation and bioirrigation by $A$. marina did not alleviate sulfide stress to seagrasses in organic sediments in the present experiment. Instead, we found synergistic negative effects of stressors (i.e., A. marina activity and sulfide toxicity from organic loading, aggravated by $A$. marina activity). This knowledge adds to our understanding of the complex interaction between seagrasses and A. marina. Although the outcome of interactions in a particular field situation cannot be predicted from our findings, our study shows that (1) increasing A. marina numbers may represent an increased threat to seagrasses, and (2) organic matter addition will further threaten seagrass beds. A. marina numbers in the Wadden Sea and the Dutch delta have increased since the 1980s (Eriksson et al. 2010; Philippart 1994; Reise et al. 2008). This increase may have been caused by eutrophication, human exploitation, and/or climate change (Reise et al. 2008; Van Beusekom 2005). Our study shows that such increases in $A$. 
marina numbers, particularly in combination with organic matter loading, can seriously threaten seagrass beds. Therefore we expect mutual exclusion rather than co-occurrence of these two ecosystem engineers, even more so as each of the two, A. marina and seagrasses, displays self-facilitating positive feedbacks (Van der Heide et al. 2011; Van Wesenbeeck et al. 2007). The occasional co-occurrence of both species in the field is thus likely to be explained by disturbance or seasonal dynamics (Eklof et al. 2011), rather than being a long-term, stable outcome of biomechanical warfare or competition.

Acknowledgments We are grateful to Niki de Lange for helping out during the experiment, to Germa Verheggen and Martin Versteeg for their technical support, to Jelle Eygensteyn for his help with the analyses, and to the people at the NIOZ Yerseke nutrient lab for their help with the nutrient analyses. We also thank three anonymous referees for their suggestions to improve the quality of our manuscript.

\section{References}

Andersen FO, Kristensen E (1992) The importance of benthic macrofauna in decomposition of microalgae in a coastal marine sediment. Limnol Oceanogr 37:1392-1403

Ashforth EJ, Olive PJW, Ward AC (2011) Phylogenetic characterisation of bacterial assemblages and the role of sulphur-cycle bacteria in an Arenicola marina bioturbated mesocosm. Mar Ecol Prog Ser 439:19-30

Asmus H, Asmus RM (1998) The role of macrobenthic communities for sediment-water material exchange in the Sylt-Rømø tidal basin. Senckenb Marit 29:111-119

Asmus RM, Jensen MH, Jensen KM, Kristensen E, Asmus H, Wille A (1998) The role of water movement and spatial scaling for measurement of dissolved inorganic nitrogen fluxes in intertidal sediments. Estuar Coast Shelf Sci 46:221-232

Banta GT, Holmer M, Jensen MH, Kristensen E (1999) Effects of two polychaete worms: Nereis diversicolor and Arenicola marina, on aerobic and anaerobic decomposition in a sandy marine sediment. Aquat Microb Ecol 19:189-204

Bertness MD, Leonard GH (1997) The role of positive interactions in communities: lessons from the intertidal habitats. Ecology 78:1976-1989

Borum J et al (2005) The potential role of plant oxygen and sulphide dynamics in die-off events of the tropical seagrass, Thalassia testudinum. J Ecol 93:148-158

Bos A, van Katwijk MM (2007) Planting density, hydrodynamic exposure and mussel beds affect survival of transplanted intertidal seagrass. Mar Ecol Prog Ser 336:121-129

Bos A, Bouma T, Dekort G, Vankatwijk M (2007) Ecosystem engineering by annual intertidal seagrass beds: sediment accretion and modification. Estuar Coast Shelf Sci 74:344-348

Bouma TJ et al (2005) Trade-offs related to ecosystem engineering: a case study on stiffness of emerging macrophytes. Ecology 86:2187-2199

Bouma TJ, Olenin S, Reise K, Ysebaert T (2009) Ecosystem engineering and biodiversity in coastal sediments: posing hypotheses. Helgol Mar Res 63:95-106

Brun FG, van Zetten E, Cacabelos E, Bouma TJ (2009) Role of two contrasting ecosystem engineers (Zostera noltii and Cymodocea nodosa) on the food intake rate of Cerastoderma edule. Helgol Mar Res 63:19-25
Bruno JF, Stachowicz JJ, Bertness MD (2003) Inclusion of facilitation into ecological theory. Trends Ecol Evol 18:119-125

Cadée GC (1976) Sediment reworking by Arenicola marina on tidal flats in the Dutch Wadden Sea. Neth J Sea Res 10:440-460

Cadée GC (2001) Sediment dynamics by bioturbating organisms. In: Reise K (ed) Ecological comparisons of sedimentary shores. Springer, Berlin, pp 127-236

Calleja ML, Marba N, Duarte CM (2007) The relationship between seagrass (Posidonia oceanica) decline and sulfide porewater concentration in carbonate sediments. Estuar Coast Shelf Sci 73:583-588

Christianen MJA et al (2013) Low-canopy seagrass beds still provide important coastal protection services. Plos One 8:e62413

Crain CM, Bertness MD (2006) Ecosystem engineering across environmental gradients: implications for conservation and management. Bioscience 56:211-218

Dean RB, Dixon WJ (1951) Simplified statistics for small numbers of observations. Anal Chem 23:636-638

Eklof JS, van der Heide T, Donadi S, van der Zee EM, O'Hara R, Eriksson BK (2011) Habitat-mediated facilitation and counteracting ecosystem engineering interactively influence ecosystem responses to disturbance. Plos One 6:e23229

Eriksson BK, van der Heide T, van de Koppel J, Piersma T, van der Veer HW, Olff H (2010) Major changes in the ecology of the Wadden Sea: human impacts, ecosystem engineering and sediment dynamics. Ecosystems 13:752-764

Flach EC, Beukeman JJ (1994) Density-governing mechanisms in populations of the lugworm Arenicola marina on tidal flats. Mar Ecol Prog Ser 115:139-149

Fonseca M (1989) Sediment stabilization by Halophila decipiens in comparison to other seagrasses. Estuar Coast Shelf Sci 29:501-507

Fonseca MS, Cahalan JA (1992) A preliminary evaluation of wave attenuation by 4 species of seagrass. Estuar Coast Shelf Sci 35:565-576

Govers et al (in revision) Toxic constraints for seagrass patch survival and expansion

Granata TC, Serra T, Colomer J, Casamitjana X, Duarte CM, Gacia E (2001) Flow and particle distributions in a nearshore seagrass meadow before and after a storm. Mar Ecol Prog Ser 218:95-106

Grilo TF, Cardoso PG, Pardal MA (2012) Implications of Zostera noltii recolonization on Hydrobia ulvae population structure success. Mar Environ Res 73:78-84

Grossmann S, Reichardt W (1991) Impact of Arenicola marina on bacteria in intertidal sediments. Mar Ecol Prog Ser 77:85-93

Hansen K, King GM, Kristensen E (1996) Impact of the soft-shell clam Mya arenaria on sulfate reduction in an intertidal sediment. Aquat Microb Ecol 10:181-194

Hines ME, Jones GE (1985) Microbial biogeochemistry and bioturbation in the sediments of Great Bay, New Hampshire. Estuar Coast Shelf Sci 20:729-742

Holmer M, Nielsen SL (1997) Sediment sulfur dynamics related to biomass-density patterns in Zostera marina (eelgrass) beds. Mar Ecol Prog Ser 146:163-171

Hylleberg J (1975) Influence of the lugworm Arenicola marina on porewater nutrient profiles of sandflat sediments. Mar Ecol Prog Ser 62:241-248

Isaksen MF, Finster K (1996) Sulphate reduction in the root zone of the seagrass Zostera noltii on the intertidal flats of a coastal lagoon (Arcachon, France). Mar Ecol Prog Ser 137:187-194

Jacobs R, Hegger HH, Raswillems A (1983) Seasonal variations in the structure of a Zostera community in tidal flats in the SW Netherlands, with special reference to the benthic fauna. Proc K Ned Akad Wetensch Ser C Biol Med Sci 86:347-375

Jones CG, Lawton JH, Shackak M (1994) Organisms as ecosystem engineers. Oikos 69:373-386 
Jørgensen BB (1982) Mineralization of organic matter in the sea bed - the role of sulphate reduction. Nature 296:643-645

Koch EW et al (2009) Non-linearity in ecosystem-services: temporal and spatial variability in coastal protection. Front Ecol Environ 7:29-37

Kristensen E (2000) Organic matter diagenesis at the oxic/anoxic interface in coastal marine sediments, with emphasis on the role of burrowing animals. Hydrobiologia 426:1-24

Kristensen E, Penha-Lopes G, Delefosse M, Valdemarsen T, Quintana CO, Banta GT (2012) What is bioturbation? The need for a precise definition for fauna in aquatic sciences. Mar Ecol Prog Ser 446:285-302

Lamers LPM, Tomassen HBM, Roelofs JGM (1998) Sulfate-induced eutrophication and phytotoxicity in freshwater wetlands. Environ Sci Technol 32:199-205

Lamers LP et al (2013) Sulfide as a soil phytotoxin-a review. Front Plant Sci 4:268

Mascaró O, Valdemarsen T, Holmer M, Pérez M, Romero J (2009) Experimental manipulation of sediment organic content and water column aeration reduces Zostera marina (eelgrass) growth and survival. J Exp Mar Biol Ecol 373:26-34

Meysman FJ, Middelburg JJ, Heip CH (2006) Bioturbation: a fresh look at Darwin's last idea. Trends Ecol Evol 21:688-695

Nielsen OI, Kristensen E, Holmer M (2003) Impact of Arenicola marina (Polychaeta) on sediment sulfur dynamics. Aquat Microb Ecol 33:95-105

Papaspyrou S, Kristensen E, Christensen B (2007) Arenicola marina (Polychaeta) and organic matter mineralisation in sandy marine sediments: in situ and microcosm comparison. Estuar Coast Shelf Sci 72:213-222

Passarelli C, Olivier F, Paterson DM, Meziane T, Hubas C (2013) Organisms as cooperative ecosystem engineers in intertidal flats. J Sea Res. doi:10.1016/j.seares.2013.07.010

Peralta G, Bouma TJ, van Soelen J, Perez-Llorens JL, Hernandez I (2003) On the use of sediment fertilization for seagrass restoration: a mesocosm study on Zostera marina L. Aquat Bot 75:95-110

Peralta G, van Duren LA, Morris EP, Bouma TJ (2008) Consequences of shoot density and stiffness for ecosystem engineering by benthic macrophytes in flow dominated areas: a hydrodynamic flume study. Mar Ecol Prog Ser 368:103-115

Peterson CH, Luettich RA, Micheli F, Skilleter GA (2004) Attenuation of water flow inside seagrass canopies of differing structure. Mar Ecol Prog Ser 268:81-92

Philippart CJM (1994) Interactions between Arenicola marina and Zostera noltii on a tidal flat in the Wadden Sea. Mar Ecol Prog Ser 111:251-257

Reise K (2002) Sediment mediated species interactions in coastal waters. J Sea Res 48:127-141

Reise K, Kohlus J (2007) Seagrass recovery in the Northern Wadden Sea? Helgol Mar Res 62:77-84

Reise K, Herre E, Sturm M (2008) Mudflat biota since the 1930s: change beyond return? Helgol Mar Res 62:13-22

Rijken M (1979) Food and food uptake in Arenicola marina. Neth J Sea Res 13:406-421

Romero J, Lee K, Perez M, Mateo MA, Alcoverro T (2006) Nutrient dynamics in seagrass ecosystems. In: Larkum AWD, Orth RJ, Duarte AC (eds) Seagrasses: biology, ecology and conservation. Springer, Dordrecht
Sand-Jensen K (1977) Effects of epiphytes on eelgrass photo-synthesis. Aquat Bot 3:55-63

Suykerbuyk W et al (2012) Suppressing antagonistic bioengineering feedbacks doubles restoration success. Ecol Appl 22:1224-1231

Timmermann K, Banta GT, Glud RN (2006) Linking Arenicola marina irrigation behavior to oxygen transport and dynamics in sandy sediments. J Mar Res 64:915-938

Tomasko DA, Lapointe BE (1991) Productivity and biomass of Thalassia testudinum as related to water column nutrient availability and epiphyte levels: field observations and experimental studies. Mar Ecol Prog Ser 75:9-17

Valdemarsen T, Kristensen E, Holmer M (2010) Sulfur, carbon, and nitrogen cycling in faunated marine sediments impacted by repeated organic enrichment. Mar Ecol Prog Ser 400:37-53

Valdemarsen T, Wendelboe K, Egelund JT, Kristensen E, Flindt MR (2011) Burial of seeds and seedlings by the lugworm Arenicola marina hampers eelgrass (Zostera marina) recovery. J Exp Mar Biol Ecol 410:45-52

Valentine JF, Heck KL, Harper P, Beck M (1994) Effects of bioturbation in controlling turtlegrass (Thalassia testudinum Banks ex König) abundance: evidence from field enclosures and observations in the Northern Gulf of Mexico. J Exp Mar Biol Ecol 178:181-192

Van Beusekom JEE (2005) A historic perspective on Wadden Sea eutrophication. Helgol Mar Res 59:45-54

Van der Heide T, Van Nes EH, Van Katwijk MM, Olff H, Smolders AJP (2011) Positive feedbacks in seagrass ecosystems - evidence from large-scale empirical data. Plos One 6:e16504

Van der Heide T et al (2012) A three-stage symbiosis forms the foundation of seagrass ecosystems. Science 336:1432-1434

Van Katwijk MM, Bos AR, De Jonge VN, Hanssen LSAM, Hermus DCR, De Jong DJ (2009) Guidelines for seagrass restoration: importance of habitat selection and donor population, spreading of risks, and ecosystem engineering effects. Mar Pollut Bull 58:179-188

Van Wesenbeeck BK, Van de Koppel J, Herman PMJ, Bakker JP, Bouma TJ (2007) Biomechanical warfare in ecology; negative interactions between species by habitat modification. Oikos 116:742-750

Vermaat JE, Verhagen FCA (1996) Seasonal variation in the intertidal seagrass Zostera noltii Hornem.: coupling demographic and physiological patterns. Aquat Bot 52:259-281

Volkenborn N, Reise K (2006) Lugworm exclusion experiment: responses by deposit feeding worms to biogenic habitat transformations. J Exp Mar Biol Ecol 330:169-179

Volkenborn N, Hedtkamp SIC, van Beusekom JEE, Reise K (2007) Effects of bioturbation and bioirrigation by lugworms (Arenicola marina) on physical and chemical sediment properties and implications for intertidal habitat succession. Estuar Coast Shelf Sci 74:331-343

Wendelboe K, Egelund JT, Flindt MR, Valdemarsen T (2013) Impact of lugworms (Arenicola marina) on mobilization and transport of fine particles and organic matter in marine sediments. J Sea Res 76:31-38

Wood ED, Armstron FA, Richards FA (1967) Determination of nitrate in sea water by Cadmium-Copper reduction to nitrite. J Mar Biol Assoc UK 47:23 